\title{
Temporal changes in metal concentrations in a polluted urban basin: the contribution of multivariate techniques to the evaluation of their recovery
}

\section{Mariel Alejandra Tripodi ( $\square$ tripodimariel@gmail.com )}

Universidad de Buenos Aires Facultad de Ciencias Exactas y Naturales https://orcid.org/0000-00028501-1563

\section{Gerardo Ruben Cueto}

Universidad de Buenos Aires Facultad de Ciencias Exactas y Naturales

\section{Emiliano Muschetto}

Universidad de Buenos Aires Facultad de Ciencias Exactas y Naturales

\section{Diego Hancke}

Universidad de Buenos Aires Facultad de Ciencias Exactas y Naturales

\section{Olga Virginia Suárez}

Universidad de Buenos Aires Facultad de Ciencias Exactas y Naturales

\section{Research Article}

Keywords: Temporal variation, Restoration polluted systems, Metals in water, Multivariate analysis, Polluted urban basin

Posted Date: November 30th, 2021

DOI: https://doi.org/10.21203/rs.3.rs-1075467/v1

License: (c) (i) This work is licensed under a Creative Commons Attribution 4.0 International License. Read Full License 


\section{Abstract}

In urban rivers in many fast-growing cities, heavy metals pollution is one of the major quality issues. Quantifying its recovery success seems to be a difficult but necessary challenge, in part, because a complex database is generally needed to assess water quality. The overall goal of this work was to evaluate temporal changes in metal concentrations in a polluted basin applying the AEM method and to determine the physicochemical and meteorological parameters associated with these changes using the RDA. We analyzed temporal changes of 15 sites located in the Matanza Riachuelo River Basin, one of the most polluted basins in the word. For this, we collected data of metal concentrations in surface water, physicochemical parameters of water and meteorological factors of eight years (2008 to 2015) in each site. The results of this work allowed make evident temporal patterns (at different scales) in metal concentrations and several factors associated with these patterns. Also, we found that the effects of physicochemical and meteorological factors in metal concentrations were dependent of each site, possibly related to the presence of different sources of pollution or characteristics of the river. Our study showed that the combination of AEM and RDA multivariate techniques is a useful tool for both detecting temporal trends in the concentrations of environmental pollutants, which are not easily detectable in highly degraded environments, and for evaluating factors associated with these changes. These techniques could be applied to different scenarios (aquatic and terrestrial) affected by the continuous advance of human activities.

\section{Introduction}

Urbanization is a global process that has great negative impacts on the hydrology and water quality of watersheds. It is considered that today there is not almost a complete natural river in the world (Wang et al. 2012). In urban rivers in many fast-growing cities heavy metals contamination is one of the major quality issues because of the practice of discharging of untreated domestic and industries wastes (Khadse et al. 2008; Reza and Singh 2010; Venugopal et al. 2009). The impacts of metals in the environment are severe and long term because they are difficult to eliminate (Ding et al. 2019; Liang et al. 2011). Metals tend to be toxic for the environment and humans as they are non-biodegradable and can accumulate in the human body system, causing damage to the nervous system (Adams et al. 2008; Clements et al. 2010; Gueu et al. 2007; Lee et al. 2007; Vinodhini and Narayanan 2008).

Rivers and streams of fresh water are important for food, services and recreation, and this is why their recovery has become a world-wide requirement (Chen 2017; Palmer et al. 2005). However, quantifying recovery success seems to be a difficult but necessary challenge. A study carried out by Jones and Schmitz (2009) in which the recovery of 240 aquatic systems was analyzed, showed that in $54 \%$ of the sites the monitoring program have not been conducted over a long time enough to detect recovery and in the $5 \%$ of them the ecosystems were irreversibly entrained into alternative states, thereby precluding recovery. Also, a complex database is generally needed for assessment of water quality as it is common the measurement of several parameters, taken from different monitoring stations and at different times (Chapman 1992; Wunderlin et al. 2001). Moreover, it is difficult to distinguish treatment effects from 
seasonal variation, episodic events and long-term climatic changes (Clements et al. 2010). Thus, to make a proper assessment of the success of recovery actions is essential determine which parameters are the most important to explain these temporal variation (Wunderlin et al. 2001).

Temporal changes in water quality parameters is commonly analyzed used univariate analyses, as multiple linear regression to evaluate changes of one parameter, or generating a water quality indices to analyze multiple parameters (Arora and Reddy 2013; Mainali and Chang 2018; Pesce and Wunderlin 2000). However, to quantify recovery success, the use of these analyses could make difficult to determine which are the pollutants that describe the changes over time and the factors associated. The multivariate techniques are appropriate for this purpose as they allow simultaneous evaluation of all variables in a complex dataset (Haase and Ellis 1987; Tripodi et al. 2021). Among them, the Asymmetric Eigenvectors Maps (AEM) analysis is a multivariate technique that was originally developed to model multivariate spatial distributions generated by a directional physical process and had usually been applied to study communities of living organisms(Legendre and Gauthier 2014). This analysis along with the redundancy analysis (RDA) are two multivariate techniques that have been useful for determining spatial patterns in metal contamination (Tripodi et al. 2021). As the processes associated with time are directional, these two techniques should also be suitable for analyzing time series of pollutants (Legendre and Gauthier 2014).

One of the 10 most polluted basins around the world corresponds to the Matanza-Riachuelo river (MRR) basin located in Argentina (Bernhardt and Gysi 2013; Mendoza et al. 2015). The MRR basin has a long history of negative environmental impacts that goes back to colonial times. The pollution caused by the agricultural and cattle industry, sewage treatment plants, garbage dump leaching as well as by industrial and domestic effluents have produced that today most of the water courses in the MRRB show severe contamination and even anoxia state (Biruk et al. 2017; Johnson 2015; Lattes et al. 2010; Nápoli 2009). One of the main pollutants of this basin are metals, showing concentrations of zinc, lead, copper, nickel and chromium in sediment samples from the Riachuelo River above the recommended levels for the protection of aquatic life (Rendina and de lorio 2012; Ronco et al. 2008). As the environmental degradation in the MRR basin reached alarming levels, in 2006, the Argentine government created the Matanza Riachuelo Basin Authority (Autoridad de Cuenca Matanza Riachuelo, ACUMAR) to develop sanitation guidelines. Among the focus of these guidelines were to generate actions to improve the life quality of the inhabitants, the recompositing of the environment in all its components (water, air and soil) and the prevention of damage (ACUMAR 2016). The monitoring of the surface water of the MRR is an action that has been quarterly carried out since 2008 to the present. This supervision includes tracking in 38 sites from the MRR basin of more than 50 representative parameters of water quality, including the measurement of physicochemical parameters, metals, organic compounds and hydrocarbons (ACUMAR 2016).

Although descriptive analyses of the metal concentration in water have been conducted in the MRR, there are no studies that focus on the temporal changes in metal concentration to evaluate the effectiveness of the actions carried out. The overall goal of this work was to evaluate temporal changes in metal 
concentrations in a polluted basin applying the AEM method and to determine the physicochemical and meteorological parameters associated with these changes using the RDA.

\section{Material And Methods \\ Description of the study area}

The MRR basin is located within the Province of Buenos Aires (90\%) and the city of Buenos Aires (10\%), Argentina. This is a plain river of short length $(80 \mathrm{~km})$, low flow $\left(8 \mathrm{~m}^{3} / \mathrm{s}\right)$ and a not very steep slope (0.35\%) (Faggi and Breuste 2015). The MRR basin is topographically divided into three sub-areas: the upper, middle and lower basins. In the upper basin, which is mainly surrounded by agricultural and cattle breeding areas (ACUMAR 2009), the water comes from plenty of streams, although only three of them are main streams. In the middle basin, which is less urbanized and industrialized than the lower basin and thus has lower pollution levels (ACUMAR 2009), these streams join to form the main watercourse, the Matanza River (Faggi and Breuste 2015). Finally, in the lower basin, which shows the highest population and industrial densities of the entire basin, the Matanza River is renamed Riachuelo about $15 \mathrm{~km}$ before discharging into the Río de La Plata River (Armengol et al. 2017). The matrix of this area is characterized by shanty towns and industries, with parks and open green areas forming patches. The main industries located here are tanneries, cold storage warehouses, and metallurgical and chemical industries (Nápoli 2009). In this subarea, the river has been channelized and rectified and thus lost its natural characteristics. The natural functioning of the basin is also affected by road and railway embankments arranged across the water courses.

Most of the people living in the MRR basin reside in houses located on the banks of the rivers with precarious and inadequate supply of basic urban services (FARN 2003; Pietri et al. 2011). This situation exposes these people to a greater health risk. In this context, the Comprehensive Environmental Health Assessment in Risk Areas in the MRR basin showed that, between 2012 and 2018, 32 of the 35 neighborhoods of the MRR basin analyzed had inhabitants with higher blood lead values than those considered healthy (ACUMAR 2018b).

\section{Determination of changes in the concentrations of metals in the MRR basin}

To model changes in the metal concentrations in the time in each site, we collected data of metal concentrations of eight years (2008 to 2015) from the surface water monitoring campaigns carried out by ACUMAR (ACUMAR 2018a). We chose 15 sites (three located in the upper basin, four in the middle and eight in the lower) that had at least twenty-five concentration measurements of each metal (Fig. 1). In each site, values of the concentrations of arsenic and five metals (cadmium, copper, chromium, nickel and lead) in superficial water were used as response datasets. 


\section{Determination of temporal variations in metal concentrations in water}

We used the Asymmetric Eigenvector Maps (AEM) to detect temporal variations in metal concentrations in the MRR. This method represents the time as a time-series eigenvectors, which the first eigenvector is a linear variable, accounting for monotonic trends in response variables. All subsequent eigenvectors have sine-wave properties and are suitable to model temporal change from slow to progressively shorter fluctuation frequencies (Blanchet et al. 2008; 2011; Legendre and Gauthier 2014; Legendre and Legendre 2012). These eigenvectors constituted the explanatory dataset used to explain temporal distribution patterns of metal concentrations in the MRR (Blanchet et al. 2008).

\section{Physicochemical parameters of water dataset}

To assess the relationship between temporal changes in metal concentrations and physicochemical water parameters in each site, we used concentrations of Electric conductivity (EC), Biological oxygen demand (BOD), Chemical oxygen demand (COD), Dissolved oxygen (DO), pH, Total Suspended solid (TSS) and Water temperature (TW) as explanatory dataset. These parameters were obtained from the same fifteen sampling sites used for the metal concentration datasets between 2008 and 2015 from ACUMAR surface water monitoring campaigns (ACUMAR 2018a).

\section{Meteorological dataset}

To assess the relationship between temporal changes in metal concentrations and meteorological variables, a dataset with the daily temperature and rainfall records from each site were provided by the National Meteorological Service of Argentina (Ezeiza station, period 2008-2016). The accumulated rainfall and the average of medium, minimum and maximum temperature 3, 7, 30, 90 and 180 days prior to each ACUMAR sampling were also analyzed.

\section{Data analyses}

To explore the relationships between metal concentrations (response dataset) and each explanatory dataset (physicochemical parameters of water, meteorological factors or temporal variations), three Redundancy Analysis (RDA) were carried out in each site (S1 to S15). In each case, to reduce the number of explanatory variables, a forward selection procedure was used to select variables for a parsimonious model (Blanchet et al. 2008). Variation partitioning was performed through partial RDA to quantify the variations in the metal concentration explained individually and jointly by all explanatory datasets (AEM, physicochemical parameters of water and meteorological factors) (Borcard et al. 1992; Meot et al. 1998). All analyses were made in the R software version 4.1.1 (https://www.R-project.org/), using the following packages: vegan package version 2.5-7 (https://CRAN.R-project.org/package=vegan) to perform RDA, VennDiagram package version 1.6.20 (https://CRAN.R-project.org/package=VennDiagram) to perform variation partitioning analysis and the adespatial package version 0.3-14 (https://CRAN.Rproject.org/package=adespatial) for forward selection in the RDA and to generate eigenvectors of the temporal dataset. Graphics were made with ggplot2 package (https://ggplot2.tidyverse.org). 


\section{Results}

Metal concentrations, physicochemical parameters of water and meteorological variables for each site in the MRR basin between 2008 and 2015.

Although there were some differences among sites, metal concentrations showed few obvious temporal trends in each site (see supplementary material). Sites in the lower basin had, on average, a greater dispersion in their metal concentrations (trace of the metal matrix values between $0.0596 \mathrm{mg}^{-\mathrm{L}^{-1}}$ in S1 and $4.1303 \mathrm{mg} \cdot \mathrm{L}^{-1}$ in S4) than sites of the middle and upper basins (trace of the metal matrix values between $0.0281 \mathrm{mg} \cdot \mathrm{L}^{-1}$ in $\mathrm{S} 13$ and $\mathrm{S} 15$ and $0.0898 \mathrm{mg} \cdot \mathrm{L}^{-1}$ in S11) and the highest value was found in site 5. Also, this site showed the highest concentrations of chromium, BOD, COD and TSS. In turn, this site had one of the lowest concentrations of dissolved oxygen in water. A general pattern of the variables analyzed and the location of the sites within the basin was not observed.

Regarding the meteorological variables in the study period, the average annual temperature ranged from $17.0^{\circ} \mathrm{C}$ to $17.7^{\circ} \mathrm{C}$ and the average annual precipitation varied between $7.1 \mathrm{~mm}$ and $10.8 \mathrm{~mm}$. In winter, the average temperature was $11.9^{\circ} \mathrm{C}$ (range $-5.3^{\circ} \mathrm{C}-34.3^{\circ} \mathrm{C}$ ) and the average of rainfall was $6.6 \mathrm{~mm}$ (range $0 \mathrm{~mm}-72.3 \mathrm{~mm}$ ). In summer, the average temperature was $23.6^{\circ} \mathrm{C}\left(\right.$ range $2.5^{\circ} \mathrm{C}-39.0^{\circ} \mathrm{C}$ ) and the average of rainfall was $10.4 \mathrm{~mm}$ (range $0 \mathrm{~mm}-92.0 \mathrm{~mm}$ ).

Metal concentrations and their temporal distribution in each site

In each site, the AEM explained between 10 and $57 \%$ of the variation in metal concentrations. All sites showed temporal changes in metal concentrations in the period studied. Each site had among one and seven significant eigenvectors and the first eigenvector (vector accounting for monotonic trends) was statistically significant in all models (Table 1). These eigenvectors were associated with the RDA axes and form different temporal pattern. In total, each site had 1 or 2 different temporal patterns of change in metal concentrations and the first RDA axis indicated the trend of temporal variation in the metal concentrations in the MRR. Between 2008 and 2012, thirteen sites (Sites 1, 2, 3, 5, 6, 7, 8, 9, 10, 11, 12, 13 and 14) showed a decrease in all metal concentrations except arsenic, whereas site 4 showed the same pattern but only for concentrations of cadmium, nickel and lead. After 2012, several sites (lower basin site 4; middle basin: sites 11 and 12; upper basin sites13,14 and 15) exhibited a reversal in this decrease, even returning to the original values of metals concentrations. The last site, site 15 , was the only that did not follow the trend and showed an increase in $\mathrm{As}, \mathrm{Cr}$ and $\mathrm{Pb}$ concentrations. Also, ten sites $(1,4,56,8$, $10,11,1213$ and 14) showed cycles (meso and micro-scale variations) in metal concentrations in superficial water (Fig. 2). 
Table 1

Significant variables of each explicative dataset ( $T$ : eigenvector number in temporal dataset; M: meteorological variables y PC: physicochemical variables of water) and their total percentage explained (\%E). 3pp= Accumulated rainfall in 3 days previous to sampling. $7 p p=$ Accumulated rainfall in 7 days previous to sampling. $30 \mathrm{pp}=$ Accumulated rainfall in 30 days previous to sampling. $90 \mathrm{pp}=$ Accumulated

rainfall in 90 days previous to sampling. $3 \mathrm{ma}=$ Average maximum temperature in 3 days previous to sampling. $180 \mathrm{ma}=$ Average maximum temperature in 180 days previous to sampling. $180 \mathrm{me}=$ Average temperature in 180 days previous to sampling. $\mathrm{BOD}=$ Biological oxygen demand. $\mathrm{COD}=$ Chemical oxygen demand. TSS= Total suspended solid. EC= Electric conductivity. DO= Dissolved oxygen. $\mathrm{TW}=$ Water temperature.

\begin{tabular}{|c|c|c|c|c|}
\hline SITE & $\mathrm{T}(\% \mathrm{E})$ & $M(\% E)$ & $\mathrm{PC}(\% \mathrm{E})$ & $\begin{array}{l}\text { TOTAL } \\
\text { EXPLAINED }\end{array}$ \\
\hline S1 & $\begin{array}{l}1-4-5-11-18-23-24 \\
(57.5 \%)\end{array}$ & $3 p p(16.2 \%)$ & $\begin{array}{l}\text { BOD - COD - TSS - EC } \\
(48.3 \%)\end{array}$ & $62 \%$ \\
\hline S2 & $1-3-23-26$ (38.5\%) & $30 p p(5 \%)$ & BOD (14\%) & $43 \%$ \\
\hline S3 & $1-3-27(40.3 \%)$ & - & $\begin{array}{l}\text { BOD - COD - DO - TSS } \\
(31.8 \%)\end{array}$ & $42 \%$ \\
\hline S4 & $\begin{array}{l}1-3-4-5-8-18-28 \\
(45.9 \%)\end{array}$ & $3 \mathrm{ma}(4.5 \%)$ & $\mathrm{EC}-\mathrm{pH}(26.7 \%)$ & $56 \%$ \\
\hline S5 & $1-7(24.4 \%)$ & - & COD - EC (31\%) & $36.2 \%$ \\
\hline S6 & $\begin{array}{l}7-10-11-12-21 \\
(28.6 \%)\end{array}$ & - & TSS (28.6\%) & $45 \%$ \\
\hline S7 & $1(9.8 \%)$ & $90 p p(9.3 \%)$ & $\begin{array}{l}\text { BOD - COD - TSS } \\
(23.9 \%)\end{array}$ & $29 \%$ \\
\hline S8 & $1-20(18 \%)$ & - & $\operatorname{COD}(7 \%)$ & $18 \%$ \\
\hline s9 & $1(17 \%)$ & - & BOD (10\%) & $18 \%$ \\
\hline S10 & $1-13(18.6 \%)$ & $30 p p(10 \%)$ & BOD (12.7\%) & $24.5 \%$ \\
\hline S11 & $1-2-3-15-21(27.1 \%)$ & - & TSS (26.3\%) & $38.7 \%$ \\
\hline S12 & $\begin{array}{l}1-2-3-4-10-14 \\
(20.4 \%)\end{array}$ & $\begin{array}{l}90 p p-180 m a-180 m e \\
(15.2 \%)\end{array}$ & BOD (11.4\%) & $29 \%$ \\
\hline S13 & $\begin{array}{l}1-2-3-4-11-25 \\
(35.8 \%)\end{array}$ & $3 p p-7 p p(15.7 \%)$ & TSS - TW -pH (20.7\%) & $55 \%$ \\
\hline S14 & $\begin{array}{l}1-2-11-13-14-15-21 \\
(41.5 \%)\end{array}$ & - & TSS (5.3\%) & $44 \%$ \\
\hline S15 & $1-3-21(25.8 \%)$ & - & BOD - COD (9.6\%) & $32.7 \%$ \\
\hline
\end{tabular}

Relationships between metal concentrations and physicochemical variables of water All the physicochemical variables of water contributed to explain the changes in metal concentrations and their significance varied in almost all sites (Table 1). In each site, these variables explained between 
$5 \%$ and $38 \%$ of changes in metal concentrations, except in a site where it had no significant contributions. In the lower basin, changes in metal concentrations were positively associated with COD (S1, S3, S5, S7 and S8), TSS (S1, S3, S6 and S7), BOD (S1, S2, S3 and S7) and pH (S4); and negatively associated with EC (S1, S4 and S5), and DO (S3). In the middle basin, BOD (S9, S10 and S12) and TSS (S11) were significant variables associated positively with metal concentration. Finally, in the upper basin the only variable positively associated with changes in metal concentrations was TSS (S13 and s14) and the significant variables negatively associated were pH and WT (both in S13); and BOD and COD (both in S15).

Relationships between metal concentrations and Meteorological variables

The meteorological variables explained a maximum of $16 \%$ of the changes in metal concentrations. In 6 to 15 sites, the significant meteorological variables were related with the rainfall. In only two sites, the significant meteorological variables were related with the temperature. Metal concentrations was positively associated with accumulated rainfall in 4 of the 6 sites (Sites 1,10,12 and 13) and negatively associated with the remaining two sites (Sites 2 and 7). Also, in two sites (S4 and S12) metal concentrations was negatively associated with temperature. Table 1 shows all the meteorological significant variables in each site.

Comparison of the influences of physicochemical variables in water, meteorological variables and temporal patterns on the variation in metal concentrations

The amount of variation in metal concentrations explained by all datasets analyzed (temporal variation, physicochemical parameters of water and meteorological factors) differed among sites (Fig. 3). The total variation in metal concentrations of each site explained by these datasets in conjunction varied between 18 and $62 \%$. Individually, in 8 of 15 sites (sites $2,4,6,8,12,13,14$ and 15) temporal dataset explained the highest amount of variance (11-39\%). In six sites (sites 1, 3, 5, 9, 10 and 11) the combined effect of temporal variation and physicochemical parameters of water was the dataset that explained the greatest amount of variance (between $9 \%$ and $30 \%$ ). In the remained site (S7), the largest amount of variation in metal concentrations (15\%) was explained by the physicochemical parameters of water individually. The meteorological factors, individually or combined, explained at most $16 \%$ of total variance (Table 1 and Fig. 3).

\section{Discussion}

Quantifying recovery success in polluted ecosystems is an urgent challenge that faces numerous difficulties due to the complexity of the datasets necessary for its useful evaluation. The results of this work showed that AEM and RDA multivariate techniques are helpful for this purpose, because they allowed make evident temporal patterns (at different scales) in metal concentrations and several factors associated with these patterns. 
In 13 of the 15 sites analyzed in the MRR basin, all metals analyzed had the same trend between 2008 and 2016, except arsenic. Possibly this is because the arsenic is mainly associated with natural contamination of water layers, the use of certain fertilizers, herbicides and pesticides; unlike the other metals analyzed that are associated with sources of industrial pollution (ATSDR 2004, 2005, 2012, 2020; WHO 2010, 2018 ). These temporal trends in metal concentrations were of three types: continuous decrease in metal concentration (ten sites), decrease until 2012 and then increase in metal concentration (four sites) or continuous increase (site 15). These results could indicate different scenarios in the current situation in the MRR basin in relation to its concentration of metals in superficial water. As proposed by (Jones and Schmitz 2009), two possible alternatives are that motoring programs have not been carried out for long time enough to observe the recovery of aquatic ecosystems or that the ecosystems were irreversibly entrained into alternative states, having no chance of recovery. The first scenario could include the 10 sites (all located in the lower or the first section of the middle basin) that have a continuously decreasing trend in their concentration of metals. According to this hypothesis, studies carried out by Casares and de Cabo (2018) in the lower basin showed a decrease in the biological oxygen demand (BOD), total ammonia nitrogen and ion chloride in superficial water between 2008 and 2016. These variations, in part, could be explained by the actions that ACUMAR undertook to carry out since 2008, which include: reduction and control of illegal industrial discharges in the basin, the removal of elements that impede the circulation of water (such as abandoned ship carcasses), relocation of the people who lived on the banks, the cleaning of open-air dumps and the cleaning and afforestation plan in some sectors (ACUMAR 2010; Faggi and Breuste 2015). Five sites (located in the middle or the upper basin) showed oscillating (or increasing) trend in their metal concentration. Two possible scenarios could be considered for these sites: having no chance of recovery or that the actions of ACUMAR are not always effective or are not carried out in a sustained manner. It is probable that ACUMAR has concentrated its actions, such as industrial reconversion plans and relocation of settlements, in the lower basin due to its high levels of pollution and the large number of marginal urban settlements located on the Riachuelo coast (Tripodi et al. 2021). On the other hand, the results of this study also showed that temporary trends had variations, seasonal or episodic events, in metal concentrations. Seasonal variations in metal contamination have been described in several studies. These variations could be explained by changes in meteorological factors among seasons, like temperature and precipitations (Clements et al. 2010).

The physicochemical and meteorological variables may influence changes in metal concentrations in superficial water. In this work, we found that the effects of physicochemical and meteorological factors in metal concentrations were dependent of each site, possibly related to the presence of different sources of pollution (industries located, proximity to settlements, agriculture, etc.), or characteristics of the river (flow, composition of their sediments, etc.). The effects of meteorological variables have been analyzed in different studies. Cánovas et al. (2012) analyzed the concentration of metals in the Odiel river (Spain) after rainfall events, finding that although most of the dissolved metals decreased their concentrations due to the dilution effect to the increase in water flow and precipitation processes; concentrations of metals (such as $\mathrm{As}, \mathrm{Pb}$ and $\mathrm{Cr}$ ) bound to particles increased due to the mobilization of sediments. In the Matanza-Riachuelo, previous studies have found the absence of the dilution effect of precipitation on the 
concentration of metals, mainly due to the characteristics of the sediments of the Riachuelo, with high levels of sulfur, and to the little dissolved oxygen in the water, as well as to the discharge to the sewage channel without previous treatment (Bargiela and de lorio 2013). Similar results were observed in streams in the Reconquista River Basin (Argentina) (Arreghini 2005). The results of this work showed a positive association between accumulated precipitation days previous to sampling and changes in the concentration of metals in 4 sites, but negative association among these variables in other 2 sites. These differences between sites in the effect of precipitation on the concentration of metals could be explained by differences in the composition of the sediments of the river bed. Sites with sediments more contaminated could lead to further resuspension of particles with metals.

On the other hand, we found a negative relationship between metals and temperature. Korfali and Davies (2003) suggested that this phenomenon could be a deposition process of metals, because the decrease in temperature could be lowered both the carbonate mineral solubility and the oxidation of organic constituents (lower oxygen content in water), and consequently lowering concentration of metals in the water. However, Hazarika and Kalita (2020) showed a positive relationship between different heavy metals and temperature in River Brahmaputra, then, possibly the effect of the ambient temperature is also affected by the composition of the sediments and the physicochemical characteristics of the water. This is consistent with the fact that meteorological variables alone explained less than $5 \%$ of the changes in metal concentrations. Although their contribution could be considered insignificant in relation to the rest of the variables, are important to consider its effect because after the rains or by decreasing the temperature the concentrations of dissolved metals in water could increase.

On the other hand, the relationship between metal concentrations and physicochemical variables of water is also important because changes in temperature, $\mathrm{pH}$, concentration of oxygen and presence of solids in water affect the bioavailability and solubility of metals (Islam et al. 2015; Lintern et al. 2018; Lyman 1995; Su et al. 2013). The results of this work showed that all the analyzed variables contributed to explain the changes in metal concentrations and their significance varied in almost all sites. The variables positively associated were BOD (8 sites), TSS (7 sites) and COD (5 sites), indicating that these variables possibly present temporal patterns similar to those of metals in the same place. These water quality parameters represent organic pollution indicator associated with anthropogenic pollution sources (Chounlamany et al. 2017; Li and Liao 2003), and the same sources of pollution (industrial waste, sewage liquids and urban runoff) release both organic matter and metals. For example, on average an effluent from a leather tanning industry has COD values of $4000 \mathrm{mgO}_{2} / \mathrm{L}, 2000 \mathrm{mgO}_{2} / \mathrm{L}$ of $\mathrm{BOD}, 150 \mathrm{mg} / \mathrm{L}$ of trivalent chromium and $2000 \mathrm{mg} / \mathrm{L}$ of suspended solids, among others pollutants (UNIDO 2011). These types of industries were responsible for $50 \%$ of the pollutants present in the water of Riachuelo (Casares and de Cabo 2018; Nápoli 2009). In this way, site 5 , which is located in the area with the highest number of leather tanning industries in the basin (Tripodi et al. 2021), showed high levels of chromium, BOD, COD and TSS. According to ACUMAR (2021b), the $42.28 \%$ of the industries that were considered polluting had adapted their processes in order to avoid environmental contamination outside the admissible limits. In addition, more than 3770 tons of solid waste per year was removed from the waters of the MRR (ACUMAR 2021a). 
These actions, as mentioned above, possibly reduced the levels of organic contaminants in water, as well as total suspended solids, and also metals. This may the reason of why in most of the sites (14 out of 15) throughout the entire basin, the change of metal concentrations were associated with at least one these three physicochemical variables. However, Casares and de Cabo (2018) found an increase in the chemical oxygen demand (COD) in three monitoring points along the lower basin of the MRR from 2008 to 2016. These results, unlike those obtained in our study, indicated a greater discharge to the river of organic compounds whose biodegradation requires more time (chlorides, nitrites, metals, sulfides, ammonia, soluble phosphorus, suspended solids), implying a possible increase in the toxicity for the species of the aquatic biota. Therefore, although it was not the objective of our study, more studies would be necessary to evaluate the temporal changes of this variable.

On the other hand, the results of our study indicated that $\mathrm{DO}$ and $\mathrm{pH}$ had significant associations with metal concentration at only one and two sites (respectively), indicating that do not influence markedly the MRR basin stretch under consideration. Organic matter dissolved in higher concentrations consumes large amounts of oxygen, thus reducing DO. In turn, due to the lack of DO, anaerobic fermentation processes are produced that release organic acids. The $\mathrm{pH}$ of the water decreases possibly due to the hydrolysis of these organic acids (Chounlamany et al. 2017; Wang et al. 2013). Therefore, these two physicochemical variables would also be related to the amount of organic matter in the water.

In the restoration of aquatic systems contaminated with metals, once the toxic input has ceased, and except for specific actions such as liming, everything else can be left to natural processes (Bradshaw 1996). An important factor that can influence the variation of the levels of physicochemical parameters and the total concentration of heavy metals is the river flow (Chapman 1992). The Matanza-Riachuelo is a plain river, with a low slope and low flow (Faggi and Breuste 2015). Rainwater flows into the main course only through 4 major tributaries (one piped), despite having hundreds of tributary streams, and all of them are highly polluted. Thus, the characteristics of the MRR significantly affect its capacity for selfpurification and the restoration processes would be more extensive in time, unlike other larger and faster rivers that have a greater dilution capacity. This highlights the importance of long-term temporary studies and adequate monitoring and analysis strategies to assess changes over time.

\section{Conclusions}

Wohl et al. (2005) suggested that self-sustaining, ecologically successful recovery efforts must be designed in relation to broad spatial (watershed) and temporal contexts. However, long-term monitoring programs that evaluate recovery of degraded ecosystems following the removal of a stressor are relatively rare (Clements et al. 2010). Therefore, the effectiveness of recovery programs is hard to asses (Bernhardt 2005; Clements et al. 2010; Jones and Schmitz 2009). The analysis proposed in this study is a useful tool for detecting temporal trends in the concentrations of environmental pollutants, which are not easily detectable in highly degraded environments and evaluating factors associated with these changes. This method of analysis could be applied to different scenarios (aquatic and terrestrial) affected by the continuous advance of human activities that generate pollution and require, therefore, a rigorous 
evaluation to avoid harmful consequences for human health and the ecosystem. For example, temporal variations of compounds derived from the mining industry in the waters near the exploitation site, or from the agrochemical compounds (fertilizers, pesticides, etc.) in both the water and the soil of areas dedicated to agriculture, among many other, could be analyzed as well as their associations with different environmental variables.

\section{Statements And Declarations}

Funding: This work was supported by Universidad de Buenos Aires, Consejo Nacional de Investigaciones Científicas y Técnicas (CONICET, Argentina) and Gobierno de la Ciudad de Buenos Aires.

Availability of data and material. Data is available in the supplementary material

Code availability: Not applicable

Authors' contributions: All authors contributed to the study conception and design. Data collection and analysis were performed by Mariel Tripodi and Gerardo Cueto. The first draft of the manuscript was written by Mariel Tripodi and all authors commented on previous versions of the manuscript. All authors read and approved the final manuscript.

Conflict of interest/competing interests: Not applicable

Ethics approval: Not applicable.

Consent to participate: Not applicable.

\section{Acknowledgments}

We are especially grateful to the National Meteorological Service and ACUMAR for the data provided that were used to perform the analysis of this paper. We would also like to thank to Pamela Tripodi for her advice in chemical interpretation and the anonymous reviewers for reading and providing useful comments on drafts of the manuscript.

\section{References}

1. ACUMAR (2009) Actualización del Plan Director Básico de Drenaje Pluvial de la Cuenca Matanza Riachuelo. Matanza-Riachuelo Basin Authority web.

https://sistemamid.com/panel/uploads/biblioteca/2015-04-12_02-59-46119345.pdf. Accessed 12 November 2021

2. ACUMAR (2010) Actualización marzo 2010 del Plan Integral de Saneamiento Ambiental de la Cuenca Matanza Riachuelo (PISA). Matanza-Riachuelo Basin Authority web. https://www.acumar.gob.ar/wp-content/uploads/2016/12/PISA-2010.pdf. Accessed 12 November 2021 
3. ACUMAR (2016) Actualización del Plan Integral de Saneamiento Ambiental (PISA): Hacia una visión compartida de la cuenca. Matanza-Riachuelo Basin Authority web. https://www.acumar.gob.ar/wpcontent/uploads/2016/12/PISA-2016.pdf. Accessed 12 November 2021

4. ACUMAR (2018a) bdh-cmr. Sistema de Gestión de Información Hidrológica. Información de calidad y dinámica de los recursos hídricos en el área de la Cuenca Matanza Riachuelo. Matanza-Riachuelo Basin Authority web. http://www.bdh.acumar.gov.ar/bdh3/index_contenido.php? xgap_historial=reset. Accessed 12 November 2021

5. ACUMAR (2018b) Población expuesta a contaminantes ambientales en zonas de la CMR. MatanzaRiachuelo Basin Authority web. https://www.acumar.gob.ar/indicadores/poblacion-expuestacontaminantes/. Accessed 12 November 2021

6. ACUMAR (2021a) Autoridad de la Cuenca Matanza Riachuelo - Limpieza de Espejo de Agua. Dirección General Ambiental. Matanza-Riachuelo Basin Authority web. http://datos.acumar.gob.ar/dataset/limpieza-de-espejo-de-agua. Accessed 11 November 2021

7. ACUMAR (2021b) Autoridad de la cuenca Matanza-Riachuelo. Agentes contaminantes identificados y adecuados. Matanza-Riachuelo Basin Authority web.

https://www.acumar.gob.ar/indicadores/agentes-contaminantes-identificados-adecuados. Accessed 11 November 2021

8. Adams RH, Guzmán Osorio FJ, Zavala Cruz J (2008) Water repellency in oil contaminated sandy and clayey soils. Int J Environ Sci Technol 5:445-454. https://doi.org/410.1007/BF03326040

9. Armengol S, Manzano M, Bea SA, Martínez S (2017) Identifying and quantifying geochemical and mixing processes in the Matanza-Riachuelo Aquifer System, Argentina. Sci Total Environ 599:14171432

10. Arora AS, Reddy AS (2013) Multivariate analysis for assessing the quality of stormwater from different Urban surfaces of the Patiala city, Punjab (India). Urban Water J 10:422-433

11. Arreghini S (2005) Influence of rainfall on the discharge, nutrient concentrations and loads of a stream of the "Pampa Ondulada" (Buenos Aires, Argentina). Limnetica 24:225-236. https://doi.org/210.23818/limn.23824.23822

12. ATSDR (2004) Toxicological profile for Copper. US Department of Health and Human Services, Public Health Service Atlanta, GA, USA. Agency for Toxic Substances and Disease Registry Web. https://www.atsdr.cdc.gov/toxprofiles/tp132.pdf. Accessed 12 November 2021

13. ATSDR (2005) Toxicological profile for Nickel. US Department of Health and Human Services, Public Health Service, Atlanta, GA, USA. Agency for Toxic Substances and Disease Registry Web. https://www.atsdr.cdc.gov/toxprofiles/tp15.pdf. Accessed 12 November 2021

14. ATSDR (2012) Toxicological profile for Chromium. US Department of Health and Human Services, Public Health Service, Atlanta, GA, USA. Agency for Toxic Substances and Disease Registry Web. https://www.atsdr.cdc.gov/toxprofiles/tp7.pdf. Accessed 12 November 2021

15. ATSDR (2020) Toxicological profile for Lead. US Department of Health and Human Services, Public Health Service, Atlanta, GA, USA. Agency for Toxic Substances and Disease Registry Web. 
https://www.atsdr.cdc.gov/toxprofiles/tp13.pdf. Accessed 12 November 2021

16. Bargiela M, de lorio AF (2013) El caso Cuenca Matanza Riachuelo: La fase sólida y su influencia sobre la calidad del agua.Encrucijadas $56: 78-83$

17. Bernhardt A, Gysi N (2013) The world's worst 2013: The top ten toxic threats. Blacksmith Institute and Green Cross Switzerland, New York, NY

18. Bernhardt ES (2005) Synthesizing U.S. River Restoration Efforts. Science 308:636-637

19. Biruk LN, Moretton J, Fabrizio de lorio A, Weigandt C, Etcheverry J, Filippetto J, Magdaleno A (2017) Toxicity and genotoxicity assessment in sediments from the Matanza-Riachuelo river basin (Argentina) under the influence of heavy metals and organic contaminants. Ecotoxicol Environ Saf 135:302-311

20. Blanchet FG, Legendre P, Borcard D (2008) Modelling directional spatial processes in ecological data. Ecol Model 215:325-336

21. Blanchet FG, Legendre $P$, Maranger R, Monti D, Pepin P (2011) Modelling the effect of directional spatial ecological processes at different scales. Oecologia 166:357-368

22. Borcard D, Legendre P, Drapeau P (1992) Partialling out the spatial component of ecological variation. Ecology 73:1045-1055

23. Bradshaw AD (1996) Underlying principles of restoration. Can J Fish Aquat Sci 53:3-9

24. Cánovas CR, Olías M, Sarmiento AM, Nieto JM, Galván L (2012) Pollutant transport processes in the Odiel River (SW Spain) during rain events. Water Resour Res 48:W06508

25. Casares MV, de Cabo LI (2018) Análisis de tendencias de variables indicadoras de calidad de agua para el Riachuelo (Cuenca Matanza-Riachuelo, Argentina). Rev Int Contam Ambient 34:651-665

26. Clements WH, Vieira NKM, Church SE (2010) Quantifying restoration success and recovery in a metal-polluted stream: a 17-year assessment of physicochemical and biological responses. J Appl Ecol 47:899-910. https://doi.org/810.1111/j.1365-2664.2010.01838.x

27. Chapman D (1992) Water quality assessments - A Guide to use of biota, sediments and water in environmental monitoring. Chapman \& Hall (on behalf of UNESCO, WHO and UNEP)

28. Chen WY (2017) Environmental externalities of urban river pollution and restoration: A hedonic analysis in Guangzhou (China). Landsc Urban Plann 157:170-179

29. Chounlamany V, Tanchuling MA, Inoue $T$ (2017) Spatial and temporal variation of water quality of a segment of Marikina River using multivariate statistical methods. Water Sci Technol 76:1510-1522

30. FARN (2003) Informe Especial sobre la Cuenca Matanza-Riachuelo. Environment and Natural Resources Foundation Web. https://farn.org.ar/cpt_documentos/informe-especial-sobre-la-cuencamatanza-riachuelo/ Accessed 11 November 2021

31. Ding X, Tan Y, Hou B (2019) Spatio-Temporal Variation of Heavy Metal Pollution during Accidents: A Case Study of the Heshangshan Protected Water Area, China. Sustainability 11:6919

32. Faggi AM, Breuste J (2015) Matanza-Riachuelo river basin. An ecological perspective on the recovery of its banks. Universidad de Flores, Buenos Aires 
33. Gueu S, Yao B, Adouby K, Ado G (2007) Kinetics and thermodynamics study of lead adsorption on to activated carbons from coconut and seed hull of the palm tree. Int J Environ Sci Tech 4:11-17

34. Haase RF, Ellis MV (1987) Multivariate analysis of variance. J Couns Psychol 34:404-413

35. Hazarika AK, Kalita U (2020) Incidence of heavy metals and river restoration assessment of a major South Asian transboundary river. Environ Sci Pollut Res 27:31595-31614

36. Islam MS, Ahmed MK, Raknuzzaman M, Habibullah -Al- Mamun M, Islam MK (2015) Heavy metal pollution in surface water and sediment: A preliminary assessment of an urban river in a developing country. Ecol Indicators 48:282-291

37. Johnson BG (2015) Un abordaje interdisciplinario para rehabilitar las riberas de la CuencaMatanzaRiachuelo Terra Mundus2:1-18

38. Jones HP, Schmitz OJ (2009) Rapid Recovery of Damaged Ecosystems. PLoS ONE 4:e5653

39. Khadse GK, Patni PM, Kelkar PS, Devotta S (2008) Qualitative evaluation of Kanhan river and its tributaries flowing over central Indian plateau. Environ Monit Assess 147:83-92

40. Korfali SI, Davies BE (2003) A comparison of metals in sediments and water in the River NahrIbrahim, Lebanon: 1996 and 1999. Environ Geochem Health 25:41-50

41. Lattes AE, Donati JM, Zuloaga nG (2010) Dinámica de una ciudad: Buenos Aires, 1810 - 2010. Dirección General de Estadística y Censos Gobierno de la Ciudad Autónoma de Buenos Aires Web. https://www.estadisticaciudad.gob.ar/eyc/wpcontent/uploads/2015/09/dinamica_de_una_ciudad_2010.pdf. Accessed 12 November 2021

42. Lee CSL, Li X-D, Zhang G, Li J, Ding A-J, Wang T (2007) Heavy metals and Pb isotopic composition of aerosols in urban and suburban areas of Hong Kong and Guangzhou, South China-Evidence of the long-range transport of air contaminants. Atmos Environ 41:432-447

43. Legendre P, Legendre L (2012) Multiscale analysis: spatial eigenfunctions. Numerical Ecology. Elsevier, Amsterdam

44. Legendre P, Gauthier O (2014) Statistical methods for temporal and space-time analysis of community composition data. Proc R Soc B 281:20132728

45. Li J, Liao WG (2003) An analysis on the possibilities of eutrophication in the Three Gorges Reservoir. Sci Tech Rev 9:49-52

46. Liang N, Yang L, Dai J, Pang X (2011) Heavy Metal Pollution in Surface Water of Linglong Gold Mining Area, China. Procedia Environ Sci 10:914-917

47. Lintern A, Webb JA, Ryu D, Liu S, Bende-Michl U, Waters D, Leahy P, Wilson P, Western AW (2018) Key factors influencing differences in stream water quality across space. WIREs Water 5:e1260

48. Lyman WJ (1995) In: Rand GM (ed) Transport and trasformation processes.. In: Taylor \& Francis

49. Mainali J, Chang H (2018) Landscape and anthropogenic factors affecting spatial patterns of water quality trends in a large river basin, South Korea. J Hydrol 564:26-40

50. Mendoza RE, García IV, de Cabo L, Weigandt CF, Fabrizio de lorio A (2015) The interaction of heavy metals and nutrients present in soil and native plants with arbuscular mycorrhizae on the riverside in 
the Matanza-Riachuelo River Basin (Argentina). Sci Total Environ 505:555-564

51. Meot A, Legendre P, Borcard D (1998) Partialling out the spatial component of ecological variation: questions and propositions in the linear modelling framework. Environ Ecol Stat 5:1-27

52. Nápoli AM (2009) In: Paola MED, Sangalli F, Caorsi S (eds) Una política de estado para el Riachuelo.. In: Fundación Ambiente y Recursos Naturales (FARN), Buenos Aires

53. Palmer MA, Bernhardt ES, Allan JD, Lake PS, Alexander G, Brooks S, Carr J, Clayton S, Dahm CN, Follstad Shah J, Galat DL, Loss SG, Goodwin P, Hart DD, Hassett B, Jenkinson R, Kondolf GM, Lave R, Meyer JL, O'Donnell TK, Pagano L, Sudduth E (2005) Standards for ecologically successful river restoration: Ecological success in river restoration. J Appl Ecol 42:208-217

54. Pesce SF, Wunderlin D (2000) Use of water quality indices to verify the impact of Córdoba City (Argentina) on Suquía River. Water Res 34:2915-2926

55. Pietri DD, Dietrich P, Mayo P, Carcagno A (2011) Evaluación multicriterio de la exposición al riesgo ambiental mediante un sistema de información geográfica en Argentina. Rev panam salud pública 30:377-387

56. Rendina A, de lorio AF (2012) Heavy metal partitioning in bottom sediments of the MatanzaRiachuelo River and main tributary streams. Soil Sediment Contam 21:62-81

57. Reza R, Singh G (2010) Heavy metal contamination and its indexing approach for river water. Int J Environ Sci Technol 7:785-792

58. Ronco A, Peluso L, Jurado M, Bulus Rossini G, Salibian A (2008) Screening of sediment pollution in tributaries from the Southwestern Coast of the Rio de la Plata Estuary.Lat Am J Sedimentol Basin Anal15:67-75

59. Su S, Xiao R, Mi X, Xu X, Zhang Z, Wu J (2013) Spatial determinants of hazardous chemicals in surface water of Qiantang River, China. Ecol Indicators 24:375-381

60. Tripodi M, Cueto G, Suárez O (2021) Evaluation of changes in spatial pattern of metals pollution in surface water using multivariate analysis: case study an urban basin from Buenos Aires, Argentina.Urban Water Journal:1-8. https://doi.org/10.1080/1573062X.2021.1925708

61. UNIDO (2011) Introduction to treatment of tannery effluents. What every tanner should know about effluent treatment. United Nations Industrial Development Organization, Viena

62. Venugopal T, Giridharan L, Jayaprakash M, Velmurugan PM (2009) A comprehensive geochemical evaluation of the water quality of River Adyar, India. Bull Environ Contam Toxicol 82:211-217

63. Vinodhini R, Narayanan M (2008) Bioaccumulation of heavy metals in organs of fresh water fish Cyprinus carpio (Common carp). Int J Environ Sci Technol 5:179https://doi.org/110.1007/BF03326011

64. Wang J, Liu XD, Lu J (2012) Urban river pollution control and remediation. Procedia Environ Sci 13:1856-1862

65. Wang L, Wang M, Peng C, Pan J (2013) Toxic Effects of Nano-CuO, Micro-CuO and Cu2+ on Chlorella $s p$. J Environ Prot Sci 4:86-91 
66. WHO (2010) World Health Organization. Exposure to cadmiun: A major public health concern. Geneva, Switzerland

67. WHO (2018) Arsenic. World Health Organization Web. https://www.who.int/news-room/factsheets/detail/arsenic. Accessed 11 November 2021

68. Wohl E, Angermeier PL, Bledsoe B, Kondolf GM, MacDonnell L, Merritt DM, Palmer MA, Poff NL, Tarboton D (2005) River restoration. Water Resour Res 41:W10301

69. Wunderlin D, Díaz MadP, Amé MaV, Pesce SF, Hued AC, Bistoni M (2001) Pattern recognition techniques for the evaluation of spatial and temporal variations in water quality. A case study: Suquía River Basin (Córdoba-Argentina). Water Res 35:2881-2894

\section{Figures}

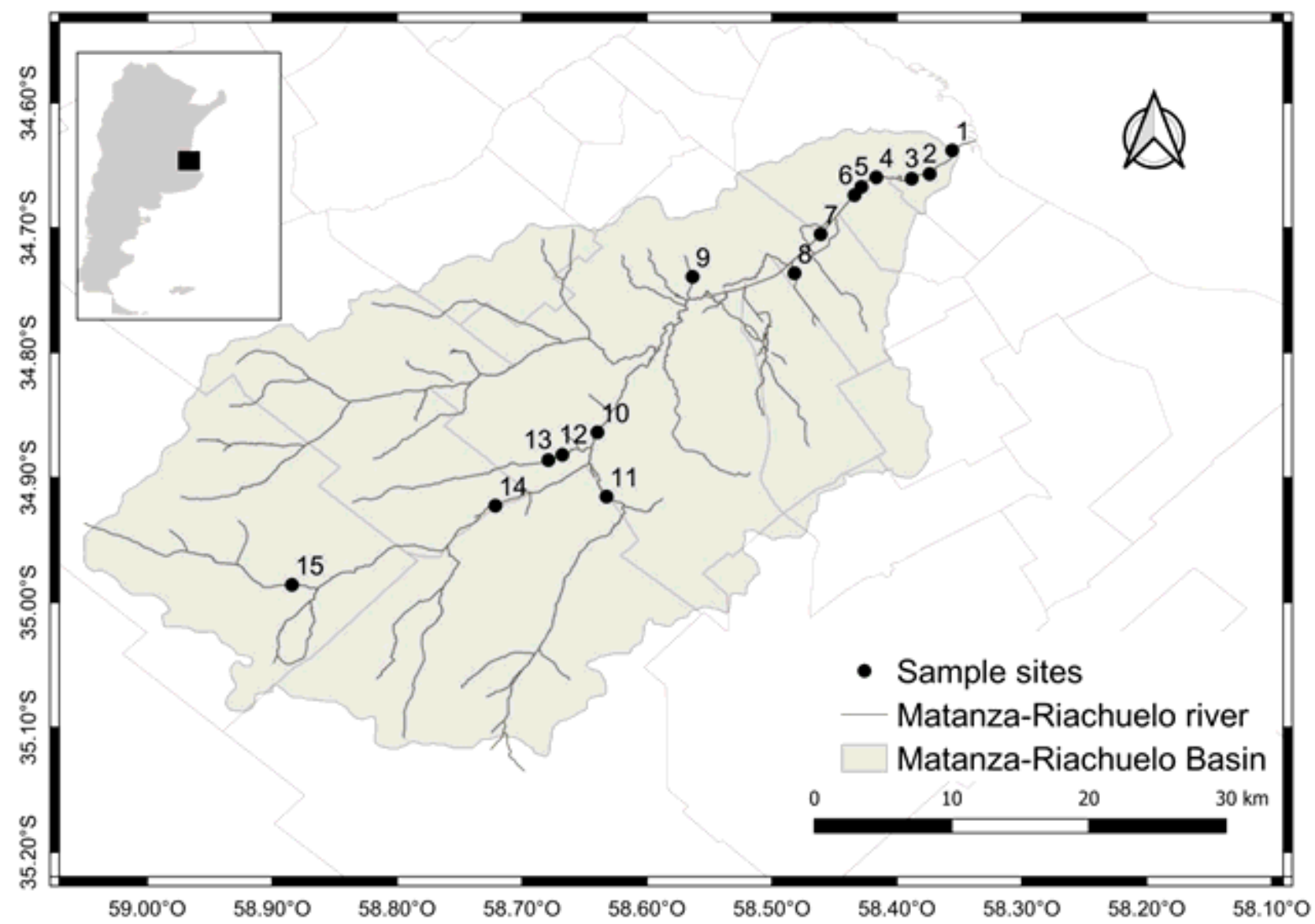

Figure 1

Location of the 15 sites analyzed in the Matanza-Riachuelo river (MRR) basin. 
SITE 1

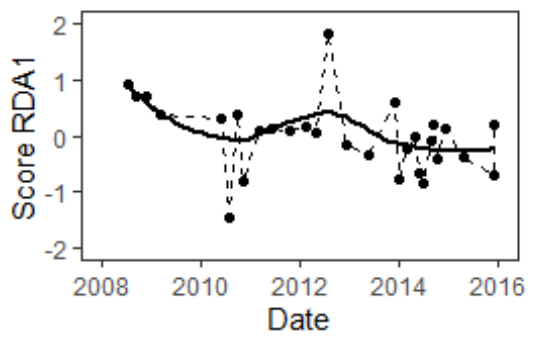

SITE 4

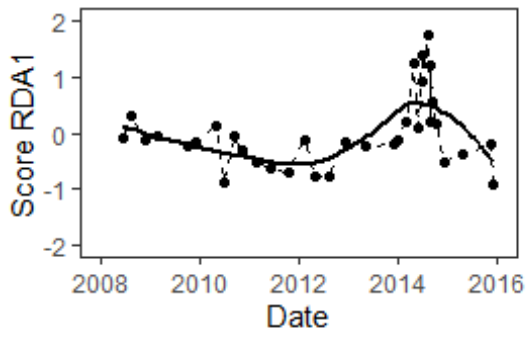

SITE 7

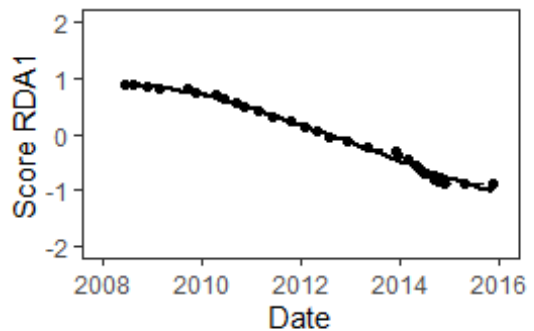

SITE 10

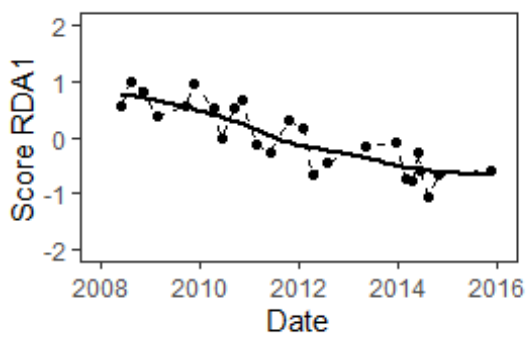

SITE 13

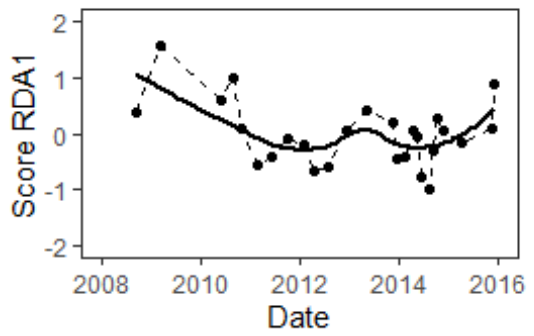

SITE 2

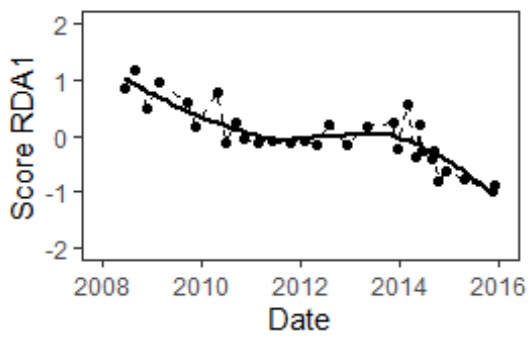

SITE 5

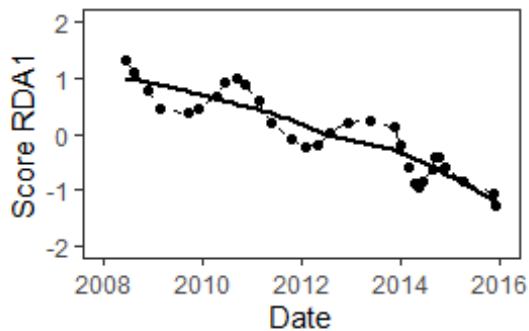

SITE 8

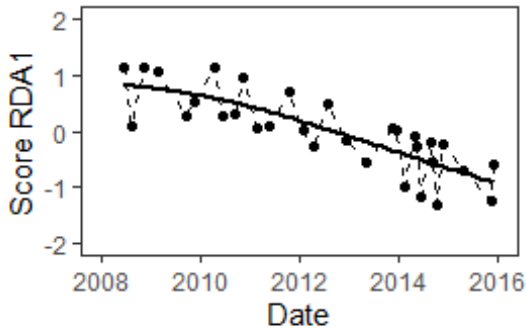

SITE 11

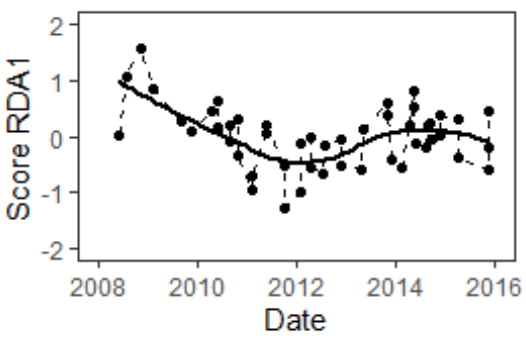

SITE 14

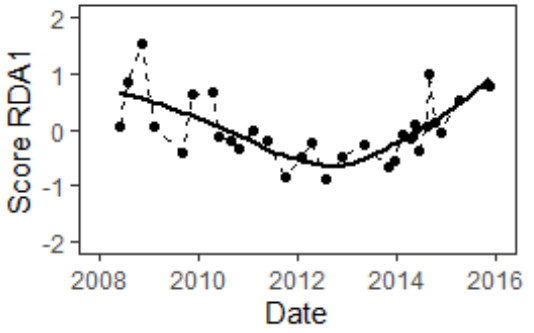

SITE 3

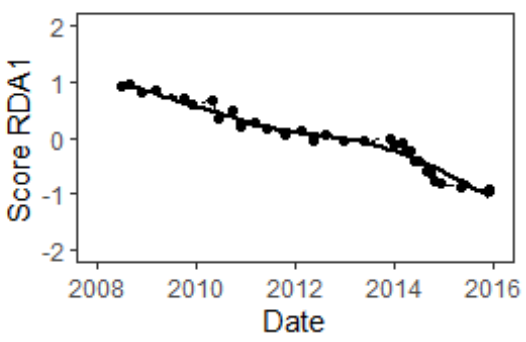

SITE 6

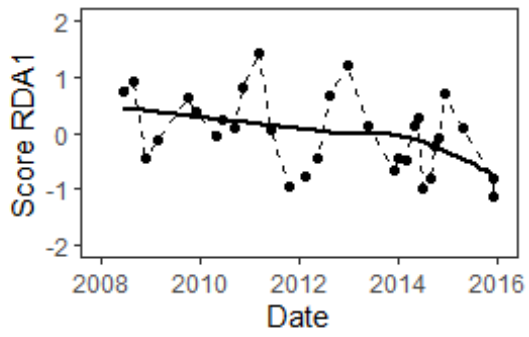

SITE 9

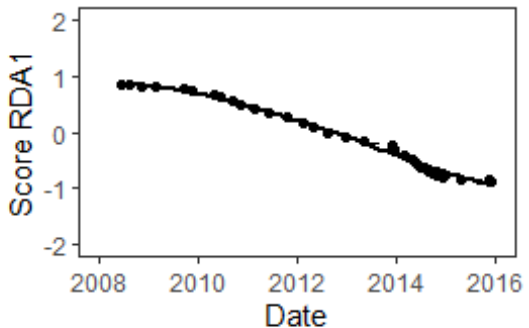

SITE 12

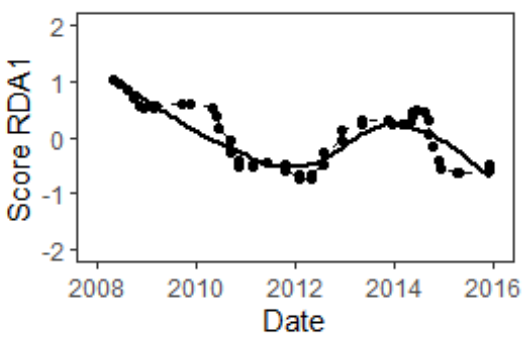

SITE 15

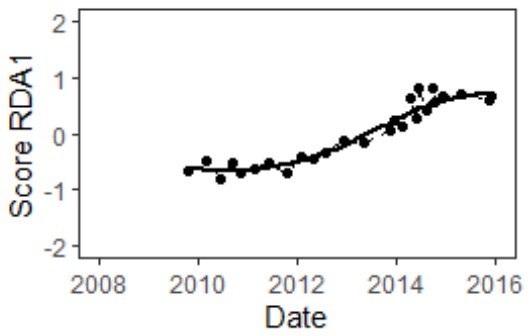

Figure 2

First RDA axis for each site between 2008 and 2016 (Value and smooth for each monitoring). These RDA axes were associated with the temporal patterns of the metal concentrations in each site. 


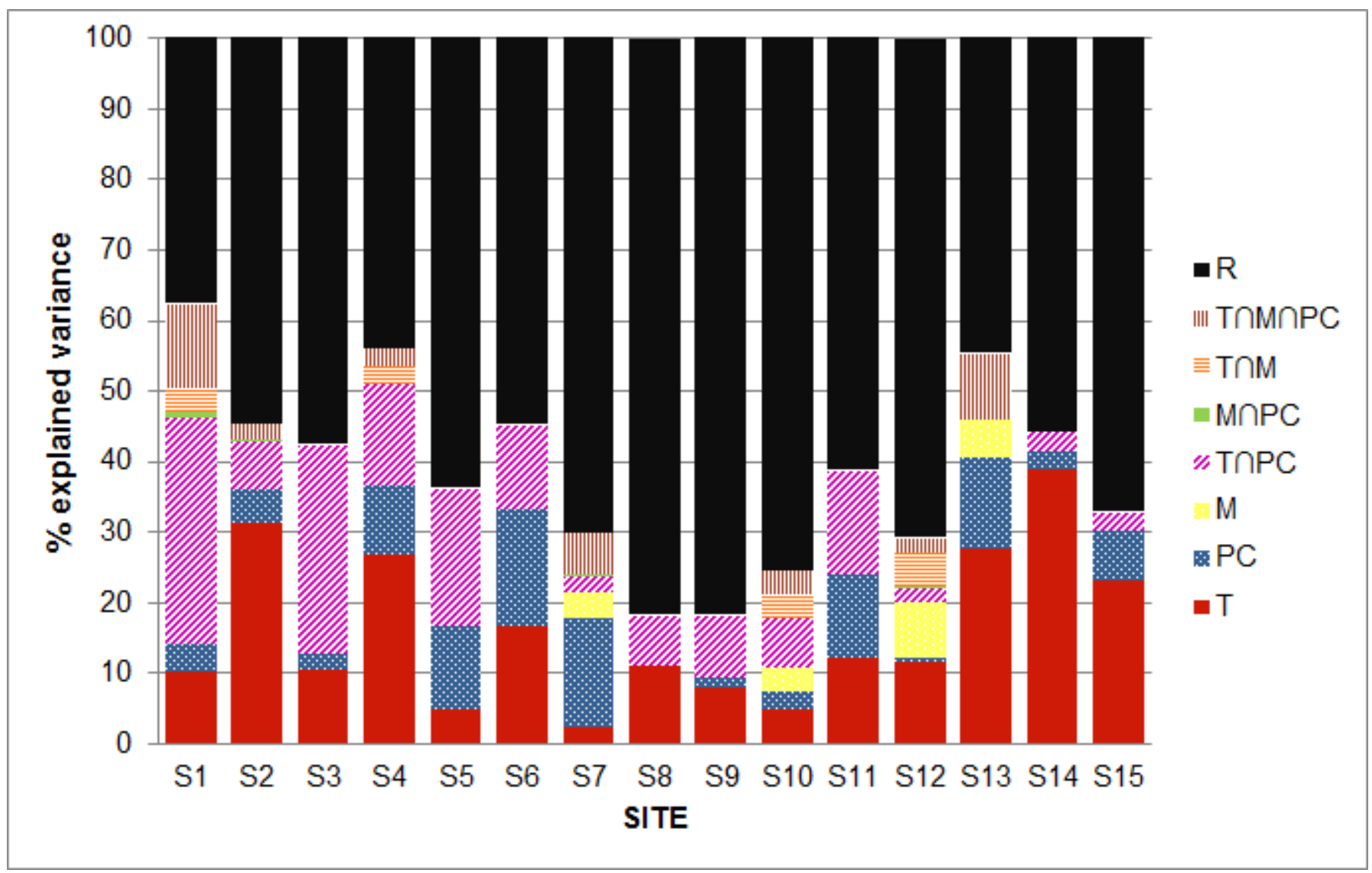

\section{Figure 3}

Variation explained in the metal concentrations for each dataset (only and in conjunction with others data sets) per site. T: temporal variables, PC: physicochemical parameters of water, M: meteorological factors, $\mathrm{T} \cap \mathrm{PC}$ : Temporal variables intersection with physicochemical parameters of water; $\mathrm{M \cap PC}$ : meteorological variables intersection with physicochemical parameters of water; $T \cap M$ : Temporal variables intersection with meteorological variables; $\mathrm{T} \cap \mathrm{M} \cap \mathrm{PC}$ : Intersection of the three datasets; $\mathrm{R}$ : residuals.

\section{Supplementary Files}

This is a list of supplementary files associated with this preprint. Click to download.

- Dataandmaterial.csv

- Supplementarymaterial.docx 